\title{
1. Introduction: rethinking ethics, economic theory and public policy
}

\section{INTRODUCTION}

The basic point of this book is to provide a robust theoretical prism that demonstrates that under reasonable conditions ethical behaviour and ethical policy is not only compatible with market economies, capitalism, globalizing capitalism, and the like, but can also be an engine of economic growth and development. But if decision-makers are informed by a different theoretical narrative, a different mental model, that speaks negatively about the economic implications of ethical behaviour and ethical policy, reasonable, smart, rational people will most probably choose to behave unethically (Altman, 2014a). Hence, the importance of providing an alternative theoretical worldview, a mental model, that suggests why and how ethical behaviour and ethical policy are not harmful to you, your family, and your society and can, indeed, be beneficial.

In this context, we also discuss the conditions which determine the extent of free choice on the market and the extent of consumer sovereignty and the ethical implications of placing limitations on free choice and therefore on consumer sovereignty. By better understanding that freedom of choice is very much conditional upon the decision-making capabilities of individuals, this allows us to more deeply assess the roots of errors in decision-making - is it hardwired in the human brain or is it more socially and institutionally determined? This dramatically affects the ethics of how and when one intervenes in the broader decision-making process and the ethics of limiting freedom of choice through government intervention in the domain of choice. ${ }^{1}$

1 For some relatively recent contributions to ethics and the economy, see DeMartino and McCloskey (2016), Gintis (2003), Rothschild (1992), Sen (1988) and White (2019). 


\section{ETHICS AND MARKETS}

There are those who say that ethical behaviour is not consistent with markets, both on the right and left. Others pronounce that ethical behaviour is consistent with markets and even with highly competitive markets. There are those who would add that ethical behaviour is even good for capitalism (good capitalism). It is good for the wellbeing of the population at large and it is good for productivity and even for profits. This is certainly a type of argument that Adam Smith (1937) of the Wealth of Nations, first published in 1776, would be happy with. Smith meant to contribute to the overthrow of the then dominant forms of market economies, which were far from free, and were controlled by the few, and replace it with 'free' market capitalism that held out the serious potential to significantly improve the wellbeing of the population in general.

Others claim that ethical behaviour is an inevitable by-product of modern capitalism and the market economy. The more globalized capitalism becomes, the more ethical should our societies become. A contemporary and eloquent articulation of this view is presented by Deirdre McCloskey (2006a, 2006b) in her discourse on Bourgeois Virtues. Of course, this inevitable process, contingent upon allowing for market capitalism to flourish, is very much assumed to be compatible with 'free' market economies, with competitive market economies.

We also have contrary narratives about how markets lead to prosperity for all but not if firms are obliged to be engaged in socially responsible or ethical behaviour (Friedman, 1970). Wealth creation is regarded as the highest form of ethical behaviour. Somehow, the good life for all will be achieved, eventually, but the key to unlocking the doors to the good life is not interfering with markets by forcing firms to be ethical or allowing firm owners or managers to behave ethically to start off with. This would only undermine the ability of capitalism to eventually bring prosperity to all. Hence, in effect, and practically speaking, ethical practices are incompatible with vibrant capitalist societies.

Others insist that markets and capitalism must be replaced with some other socio-economic systems (often very vaguely specified) for ethical behaviour to prevail. Here too, on the 'far' left ethical behaviour is considered to be inconsistent with markets and capitalism, in general. This case loosely rests on the economics of Karl Marx. Marx regarded capitalism to be highly progressive as a platform from which a 'utopian' communist society would be launched eventually and inevitably. He considered interventions into the economy, such as unions and improved working conditions, will generate higher costs and lower profits, resulting in an 
economic crisis that brings the system back to its previous 'less ethical' (my term) level of capitalist normality.

This type of pessimism is reflected, curiously enough, in the dominant and respected economic theory of today. This is often referred to as neoclassical economics or, often by non-economists, as neoliberal economics. Robust theory, it is argued, demonstrates that ethical behaviour comes at an economic cost, probably at a high economic cost, with the burden falling largely and disproportionately on those who can least afford it. Eventually, in the long run, we'll all benefit from the fruits of free market capitalism. But, in the meantime, let's keep the brakes on ethical behaviour and policy. Those versed in the conventional economic wisdom do not necessary oppose ethical behaviour or policy that impacts on the firm. But they forcefully argue that one must recognize the costs to individuals and to society at large of engaging in such policy, such as increased unemployment, lower growth and lower levels of income. Basically, you can't have your ethical cake and eat it too, at least not in the short run.

What is ethical can be subject to debate and is largely something that is more of a social norm that has evolved over time. It represents an understanding of what's right versus what's wrong or inappropriate behaviour. For this norm to have effect, there needs to be a consensus amongst members of society that behaving in a particular fashion or adopting a particular policy is the right (ethical) thing to do. And what some individuals might deem to be ethical or moral (individually based) could involve discrimination and even genocide. Members of the Klan and of neo-Nazi or neo-Fascist organizations or groups that promote gender discrimination consider themselves to be quite ethical. Much depends on how people are educated and the mental models or theories and their underlying assumptions that either explicitly or implicitly inform their ethical thinking (DeMartino, 2011; Frank, 1996, 2004; Frank et al., 1993).

Mental models help inform the choices we make (Altman, 2014a). If you believe that immigrants will take your job you'll oppose immigration, if you believe that having a greener economy will cost you your job you'll oppose efforts to encourage a greener economy, if you believe that higher wages for others will harm the economy you'll oppose minimum wages and unions and other such interventions in the economy, and if you believe that those who are different from you (outsiders) such as Jews, Gypsies and Muslims undermine your economy and fracture your communities you might even support ethnic cleansing, genocide. In all of these cases, armed with what I would argue are false mental models, you will invariably believe that you are behaving ethically, although some will simply be following the leader or the herd - nothing necessarily unethical about this, given the mental model you employ to inform the choices you 
make. Hence, the importance of education and, relatedly, theory, mental models and decision-making narratives, for the choices that impact on how ethically we choose to behave and how ethical our societies become.

But in this book, we use a very specific definition of ethical behaviour. As discussed in Chapter 2, ethical behaviour or policy is defined as behaviour and policy related to improving the wellbeing of members of society. Improving working conditions, increasing real wage rates, firms contributing to the wellbeing or the greater good of the community in which they are embedded, reducing or putting an end to discrimination would all fit into our definition of ethical behaviour. This could also involve preventing harm to be done by one person to another. Ethical policy could, therefore, reduce the wellbeing of those whose behaviour causes harm to others. Therefore, we try to prevent murder and rape, even when this is upsetting to someone who would prefer to murder or rape. And we would regulate firms polluting the environment. Here we have negative externalities imposed by the firm on society at large and ethical policy is directed towards forcing firms to internalize these negative externalities - very much part and parcel of the conventional economics toolbox.

But here conventional economics predicts that this 'ethical' behaviour will impose higher costs to the firm, with negative consequences for employment and economic growth. The same would be said about policy that would improve the wellbeing of workers and their communities. We have freedom of choice, but the ethical choices result in economic harm to society and the harm can be so great that most people would prefer the free market outcomes, hoping that markets will deliver the good life, eventually, sometime in the long run.

The theoretical frames, mental models, introduced in this book, build on a literature related to behavioural theories of the firm, institutional economics (that institutions matter significantly to economic outcomes), choice theory, and the capabilities approach to socio-economic analysis pioneered by Martha Nussbaum (2000, 2003) and Amartya Sen (1987, 1988). This narrative also builds upon my prior theoretical contributions in these areas which, in turn, builds upon the work of Harvey Leibenstein (1966), Herbert Simon (1987), Richard Cyert and James March (1963 [1992]), Douglass North (1971), John Commons (1959), George Akerlof (1970, 2002), George Akerlof and John Shiller (2009), John Harsanyi (1982) (choice theory), Vernon Smith (2003), Gary Becker (1996) (personnel and social capital and importance of sociological variables impacting decision-making) as well as the research of Daniel Kahneman (2003) and Amos Tversky and Daniel Kahneman (1981) (heuristics and biases), Herbert Gintis (2003) and Samuel Bowles (2016; see also Bowles and Gintis, 2013) (the importance of co-operative behaviour, fairness, morals 
to socio-economic development), ${ }^{2}$ Albert Hirschman (1970) (the significance of agency in determining socio-economic outcomes and wellbeing), Kahneman (2011) (slow and fast thinking), and that of Gerd Gigerenzer (2007) (fast and frugal heuristics). It is also informed by the insights on ethical or virtuous behaviour in capitalist economies by Deirdre McCloskey (2006a, 2006b), amongst others. ${ }^{3}$

One fundamentally important insight introduced in this book is that in a more realistic model of the firm we should not assume that all members of the firm, workers, managers and owners alike, are typically working as hard or as smart as they might, given their incentive environment and their preferences as well as the mental models which inform their choices. Unlike in the conventional modelling one can have effort discretion. In this scenario, firm productivity need not be as high as it might otherwise be. This state of affairs is referred to by Leibenstein (1966) as X-inefficiency in production. X-inefficiency could also be consistent with the preferences of firm decision-makers and, indeed, of all firm members, given the incentive environment and the mental models which they employ.

I argue that this inefficient behaviour is consistent with smart or rational individuals or agents. Moreover, I argue that given effort discretion and $\mathrm{x}$-inefficiency, ethical behaviour which is costly to the firm incentivizes the firm to become more $\mathrm{x}$-efficient, more productive. This increased productivity can offset the costs of the firm becoming more ethical. These cost offsets are increased when technological change is motivated by the increased costs of the firm becoming ethical or more ethical. Hence, an ethical firm can be cost competitive with relatively less ethical competitors. But there need not be any pressing incentive for the less ethical firms to become more ethical, since they are cost competitive with more ethical firms, whilst remaining relatively unethical.

Although ethical behaviour increases the wellbeing of most firm members and grows the economic pie, in this scenario one would not expect the more ethical firms to drive the less ethical firms out of the market.

2 We don't pay much attention to this book on the importance of co-operation to human socio-economic development. Bowles and Gintis (2013; see also Bowles, 2016) make the case that we are a co-operative species. We focus on the ethical domain. Co-operation can take on many forms, inclusive of free labour, slavery, serfdom and indentured servitude. From the perspective of this book co-operation need not take on an ethical focus. And ethical co-operation is, actually, one possibility amongst a large array of co-operative forms of organization. I would argue that it is the ethical type of co-operation that yields that greatest socioeconomic benefits. But it need not be what's adopted by the dominant rationale of decision-makers.

3 References are found below. 
But more importantly, in this modelling scenario, ethical behaviour is compatible with vibrant competitive markets and overall, with capitalist production. Capitalism does not preclude firms becoming more ethical. But, on the other hand, there is no ethical imperative inherent in capitalist economies. Firm decision-makers are not compelled to become more ethical by market forces. And they need not choose to become more ethical if they feel more comfortable with things as they are, even if they believe that becoming more ethical will not threaten the survival of the firm or its competitive position. Becoming ethical is very much dependent on the preferences of decision-makers, who influence decision-makers, the ability of economic agents to influence decision-makers and the decision-making process (the effective voice of economic agents; their ability to speak out without fear of retribution) (Hirschman,1970), the mental models or theoretical frames used by decision-makers and economic agents writ large.

Another important aspect of ethics addressed in this book relates to preference formation and the ability of individuals to realize their preferences. Conventional theory tends to assume that preferences are given and that the revealed preferences of individuals, through the choices they make or their expressed opinions, represent their true preferences, their deep and fundamental preferences. We discuss the conditions under which individuals can form true preferences and actualize these preferences. Absent these conditions, individuals' freedom of choice, their consumer sovereignty, is quite limited and highly constrained. This can also result in individuals making what appear to be errors in decision-making or biased decisions, where these are actually sub-optimal but rational choices limited by the decision-makers' capabilities and their decision-making environment. I refer to this as $\mathrm{x}$-inefficiency in preference formation and in choice behaviour (Altman, 2010). This narrative builds upon the research of Nussbaum (2003) and Sen (1987) on the capabilities approach and that of Harsanyi (1982) on preference formation and decision-making.

Related to this, we discuss how the true preferences of individuals can reflect the best interest of decision-makers. An important issue raised by the 'nudging' perspective in behavioural economics is whether individuals have the physiological/neurological capabilities to actually know (true preferences) what is their own best interest. Hence, in a very real sense, all too often, individuals don't know the difference between right and wrong with regards to what's in their own best interest. This analytical perspective tends to be highly inconsistent with the notion of consumer sovereignty as it speaks very favourably for interventions to alter the choices of individuals towards what experts or choice architects believe to be in the best interest of consumers. Hence, the ethical position to take with regards to consumer choice is not to respect consumer sovereignty, but rather to 
violate its first principles when the expert deems that such intervention will increase the wellbeing of the consumer (Thaler and Sunstein, 2008). But from the perspective of $\mathrm{x}$-inefficiency in preference formation and consumer choice, poor or sub-optimal choices can typically be attributed to capability gaps which can be filled by providing individuals with the means to achieve and then realize their true preferences. Here consumer sovereignty is respected by government and communities, providing consumers with the means to best achieve consumer sovereignty given the real world of bounded rationality.

It is worth mentioning in this introduction what we pay little attention to in this book. This is the importance of alternative organizational forms to introducing different levels of ethical practice into the firm in a competitive market economy. To the extent that ethical considerations won't damage the competitiveness of the firm and the resulting importance of preferences and mental models to the determination of how ethical a firm is and becomes, how a firm is organized can be of fundamental importance. In the traditional investor-owned firms, decisions are made by firm owners and their representatives. The object is to maximize profits, broadly speaking. How this is achieved is not of considerable concern especially to the economic theorists who inform policy pundits and experts. Profit maximizers locate optimal methods of maximizing profits in the black box of the firm. The practical methodologies of so doing are informed by mental models adopted by decision-makers and this, typically, is the conventional model wherein ethical practices cause economic harm to the firm.

However, an alternative mode of firm organization, which is of significance in the world economy, is the co-operative, or member-owned organization, which also incorporates credit unions and mutuals (Altman, 2014b). In the conventional investor-owned firm, firm members such as workers, consumers and suppliers typically have no ownership stake or voice in the firm. The objective of co-operatives is to be economically sustainable and competitive whilst maximizing the wellbeing of members. This typically involves incorporating ethical considerations into the organization of the firm because these are fundamental to maximizing member wellbeing. Co-operatives can be economically vibrant and competitive in highly competitive market economies. Their relative success testifies to this. Hence, we have a case of relatively ethical firms that are ideally driven by the ethos of maximizing long-term member benefits, that function quite well in competitive market economies. This is just one important example of markets being compatible with ethical behaviour (Altman, 2009, 2014b). But co-operatives don't dominate the market place. Markets don't force everyone into a co-op and firms don't have to take on the co-operative organizational form to be ethical (Gordon, 1996). 


\section{A BIT ABOUT OUR CHAPTERS}

In Chapter 2, 'The evolution of ethics and the market economy', we largely focus on introducing a behavioural model of the firm that can better explain the sustainability, competitiveness and efficacy of the ethical firm. This modelling serves to tackle the question of can we expect ethical practices to spread across all firms with the spread of 'free' market capitalist economies? Or, if this is not the case, does this imply that ethical behaviours and practices damage the competitiveness of firms and come at an economic and social cost to society at large? We argue that a more realistic model of the firm helps to explain why ethical firms are economically sustainable and can, indeed, serve as an engine of economic growth. But relatively unethical firms can also remain competitive. In this type of scenario, the extent of ethical practices in the market economy very much depends on the mental models used by decision-makers, who influence the decision-making, education and preferences of decision-makers. There is considerable freedom of choice amongst decision-makers. But one point that clearly stands out in this chapter is that being ethical is not this weighty baggage that must cause economic harm, a perspective that all too many scholars and policy pundits on both the right and the left of the political spectrum subscribe to.

In Chapter 3, 'Understanding why ethical production and ethical investment can flourish in a global economy', the theoretical arguments presented in Chapter 2 are expanded upon, with more emphasis placed on the demand side. We further elaborate on how a more realistic (behavioural) theory of the firm can help explain how and why ethical practices within a firm in a highly competitive economy can be sustainable. We also discuss how the preferences of consumers for ethical products can affect the production side of the equation, especially when rational or smart individuals are willing to make economic sacrifices to purchase products produced by more ethical firms (ethical products) if they happen to be relatively higher priced. Chapter 4 , 'Ethical choices in the economic world', expands upon the demand side of ethical production discussed in Chapter 3. I argue that it is important not to model rational or smart people as being largely income or wealth maximizers (controlling for risk). One can certainly make the case that individuals typically attempt to maximize (or satisfice) on their utility or wellbeing - but it's not all about money or wealth. Hence, it's critically important to open up the objective or preference function when modelling decision-making. Depending on one's education, family, culture, peer groups, non-economic variables also play a role in determining an individual's utility or wellbeing. Sacrificing income to do the right thing, to purchase ethical products, to boycott 
non-ethical products, to tip for services, can increase the wellbeing of individuals - give them a warm glow. This provides ethical firms with an advantage over relatively unethical firms when they charge a higher price, but even more so when they can reasonably charge the same price for the same product (controlling for quality) as the relatively unethical firm. Also, consumers have tremendous power in influencing the extent to which firms produce ethically. However, much depends on the extent to which consumers know how firms produce their goods and services. In the real world of imperfect information this becomes critically important.

In Chapter 5, 'Free will in economics: is there freedom of choice?', we link the notion of freedom of choice and ethics. Freedom of choice can only exist if decision-makers aren't constrained by market or institutional variables into making one discrete choice, which may or may not be ethical. The conventional approach to decision-making is that we should respect the free choice of individuals (consumer sovereignty) and that these choices should relate to the desire of the sovereign individual to maximize her or his utility or wellbeing in terms of material wellbeing, controlling for risk. But in the conventional model, decision-makers are constrained into making a unique utility maximizing choice, given their constraints. If one is constrained into making a particular choice by prices and income, the extent of free will and free choice and, therefore, consumer sovereignty, is severely delimited. The same can be said of firm decision-makers, if they are deemed to be narrow profit maximizers where being ethical is either a highly costly or an impossible choice option. If consumer choice is to be respected (this is the right or ethical thing to do), apart from choices that cause harm to others, then free choice must be a meaningful concept people must be able to choose from a variety of options.

To allow for this one must model decision-makers as having a broader preference function that goes beyond income or wealth maximization. One must also be able to model the firm in a manner that realistically and reasonably allows for ethical choices to be made (discussed also in Chapters 2, 3 and 4). Taking this one step further, we examine the conditions required for individuals to be able to form their true preferences or their preferred preferences and the conditions under which these preferences can be realized. Conventional theory assumes that true preferences are reflected in the revealed preferences of decision-makers and that all individuals have the capabilities to realize these preferences. I argue that this assumption is all too often not the case. If free will and freedom of choice is valued then individuals must be provided with the capabilities to form their true preferences and to realize these preferences. Otherwise revealed preferences might not be a reflection of free will, freedom of choice or consumer sovereignty. Allowing for capabilities gaps in true preference formation 
and the ability to realize one's true preferences allows us to better assess and evaluate the presumed ethical (free will) choices of individuals. Chapter 6, 'The ethics of capabilities', further develops the capabilities side of this narrative discussing and elaborating upon the contributions of Amartya Sen to the capabilities approach in economics, but also those of Martha Nussbaum. Capabilities are a necessary pillar for the realization of free choice and consumer sovereignty.

In Chapter 7, 'How much are you willing to pay to be ethical? An experiment', using data from classroom experiments, we find that individuals are willing to sacrifice income to purchase products from what they deem to be relatively more ethical firms, in this case, co-operatives. This serves to test the hypothesis that individuals are solely or predominantly motivated by financial considerations (income and wealth). The notion that rational or smart people only care about money is a very narrow view of rationality. A broader perspective, discussed in the chapters above, integrates the reality that rational people target a number of things to enhance their level of wellbeing, including sacrificing some income to do what's right or ethical. That we find that individuals are willing to make financial sacrifices to behave ethically does not mean that income and prices are not important to decision-making. It is but one determinant of choice. Moreover, our finding that individuals prefer ethical products when their price is equivalent to the price of unethical products belies the assumption that individuals should be indifferent between identical products. The ethical consideration is quite important especially when no self-sacrifice is required to be ethical. And this reinforces the narrative developed in the above chapters, that ethics matter in decision-making. Moreover, individual preferences, expressed on the market place through the free will of individuals, can play an important role in determining economic outcomes.

Chapter 8, 'Why being green can make you happy and be good for the economy', is a theoretical narrative examining free will and ethical considerations as they interact in the space of green or environmentally friendly production. In this chapter, I take to task the conventional economic modelling narrative that being green necessarily carries with it significant (in terms of absolute size) economic costs. This narrative is based on the assumption of perfect or near economic efficiency (no x-inefficiency) and that technological change is exogenous, not being affected by variables interacting inside of the 'black box' of the firm or with policy variables. Also taken to task is the so-called Porter hypothesis, after Harvard academic, John Porter, who argues that being greener should not be costly to the firm and to society at large. But the Porter hypothesis is a very positive narrative without much of a theoretical infrastructure to support 
it; without a mental model or theoretical frame to inform scholars and policy pundits and decision-makers. Conventional economists critique the Porter hypothesis as having no theoretical substance and hence not worthy of serious consideration. However, by applying our behavioural model of the firm where x-efficiency is possible (as discussed especially in Chapters 2 to 4, above), one can make the case that efforts to become greener, which do generate increasing costs, also incentivize cost offsets in terms of reducing the level of x-inefficiency and inducing technological change. These cost offsets need not be large enough to generate increased profits to firms. In this case, 'rational' decision-makers are not strictly motivated to become greener even though this need not increase average costs. Becoming greener becomes a function of the preferences of decisionmakers, the mental models that they employ (the conventional model would not encourage becoming greener), and government policy. In terms of our revision to economic theory, becoming greener can increase the size of the economic pie and contribute to a more sustainable and healthier environment without threatening the competitive position of the firm or the wealth of nations.

Chapter 9, 'The road to freedom? Ethical implications of economic theory for public policy: insights from behavioural economics', examines what has become a very important theoretical intervention to public policy, rooted in the heuristics and biases approach to behavioural economics pioneered by Kahneman and Tversky. This is known as the nudging approach to public policy, which was first articulated by Thaler and Sunstein. In the original incarnation of this approach, conventional economics and the traditional liberal positive ethical approach to consumer sovereignty (respecting individual choice if this causes no harm to others) is rejected. It is argued that all too often individuals don't make decisions that are in their own best interest and that this is largely a product of the human condition. We are predisposed to make biased decisions generating errors in decision-making. All too often we don't even know what is in our best interest when we make particular decisions. Therefore, it is ethical to nudge individuals, softly or more forcefully, into making decisions that experts, referred to as choice architects, deem to be in our self-interest.

Following upon Chapters 5 and 6, I argue, building upon the bounded rationality approach to behavioural economics pioneered by Herbert Simon, that a major source for errors in decision-making is the inadequacy of capabilities required to make smart welfare improving choices, an inadequate decision-making environment, and the use of inappropriate or false mental models. Errors are not the same as persistent and hardwired biases. Repairing these decision-making gaps, as a matter of policy, would go a long way to facilitate smarter and welfare improving choices whilst largely 
respecting the choices of individuals derived from their free will and their freedom of choice. Nudging then becomes a matter of correcting for poor or false information, improved signalling, re-framing to better clarify options, transparency, model literacy (knowing and understanding available mental models), reducing the costs of making optimal decisions, as examples, which will improve a large array of decision-making processes and outcomes made voluntarily by individuals.

\section{CONCLUSION}

\section{Ethical Practices, Wellbeing and Some Stylized Facts}

In this book, I hope to provide a more robust theoretical framework to understand the realities of market economics with regards to the divergent ethical practices and with respect to the level ethical practices. This theoretical framework must be compatible with the reality that there is a positive statistical relationship between the historical and current ethical realities and the rise of 'free' market capitalism. But correlation is not the same thing as causation. However, the positive correlation between the rise of 'free' market capitalism and improvements to human wellbeing is unequivocal. And during this time there have been massive improvements to human rights and, more specifically, to gender rights. ${ }^{4}$

On average, since the rise of 'modern' capitalist society and the spread of markets and the coincidental spread of increasing doses of democratic practices (including property rights, gender rights and human rights) even in still relatively undemocratic societies, such as China, we have had the remarkable phenomenal improvement in the wellbeing of populations worldwide. This is fundamental to our point of focus on ethics in the economics domain. Here is a brief summary of what's transpired over the past two centuries (https://ourworldindata.org/).

World population has increased from about 800 million in 1820 to about 7 billion in 2019. This massive growth was a product of individuals no longer dying on a massive scale before reaching their first birthday, women no longer dying with expected and great regularity at childbirth, and large percentages of the world's population no longer dying of starvation and disease. Food production has, for the first time in human history, kept up with population growth. There is no increase in birth rates, on average, during this time. Actually, birth rates are falling as more and

4 This empirical narrative is derived from Roser et al. (2019). 
more people expect their children to survive for a long time, the cost of raising children is increasing with the empowerment of women on the labour market, and as women gain control over their reproductive selves. Only recently has the ethical ideal (for many) that we can feed our children and our families reasonably well become a reality. And this coincides with the rise of market capitalism.

Life expectancy at birth has also risen dramatically. Throughout world history life expectancy has been very low, from the data that is available, between 30 and 40 years. By the 2010s, this has increased to over 80 in all of the relatively developed economies. India is close to 70 and China is now close to 80 . People living longer is another important and recent ethical achievement and it keeps getting better, even in the less developing economies.

The persistence of poverty is another important ethical issue. Increasing real wages, employment, improved infrastructure and improved social benefits are a means towards alleviating poverty. But such life improvements are typically frowned upon by the conventional wisdom as they are assumed to increase costs of production, making economies less competitive. In 1820, between 84 and 94 per cent of the world's population lived in extreme poverty, at between $\$ 1$ and $\$ 2$ ('real' dollars) a day (adjusted for price changes and international currencies). This fell to between 55 and 72 per cent by 1955. By 1990, about 2 billion people or 36 per cent of the world's population lived in extreme poverty, at less than $\$ 1.96$ per day. By 2015 , there were 730 million or about 10 per cent of the world's population living in extreme poverty, most of these living in sub-Saharan Africa, where so many countries are plagued with war and violent civil unrest. Poverty is still a problem, but it has collapsed in both absolute numbers and percentage terms. It is important to note that in China when some freedoms and market processes were increasingly introduced, extreme poverty began to fall dramatically. By 1990, it was 67 per cent, still well above the world average. By 2017, it was less than 1 per cent. India's extreme poverty rate was 47 per cent in the early 1990s, falling to about 5 per cent by the late 2010 s. In 1990 per capita gross domestic product (GDP) was similar in both countries, quite low relative to the world average and India did a better job in reducing poverty with a similar (actually a somewhat lower) level of income than China. But by 2017, China's per capita GDP was 3.5 times greater than India's and its wellbeing outcomes bettered those of India.

One important reason for the reduction in poverty is the dramatic increase in per capita income in real terms that's taken place over the past 150-odd years. Measured in real US dollars, world per capita GDP increased from $\$ 3,700$ in 1960 to $\$ 10,600$ in 2017 . In the USA it increased from $\$ 17,000$ to $\$ 53,000$; in the UK from $\$ 14,000$ to $\$ 42,500$; in India from 
$\$ 300$ to $\$ 2,000$; and in China from $\$ 190$ to $\$ 7,300$. Just prior to China introducing more free markets, in about 1980, Chinese per capita GDP was only $\$ 350$. Hong Kong, now a quasi-independent territory of China, achieved a per capita income of $\$ 3,400$ in 1960 and $\$ 38,000$ in 2017. Of course, Hong Kong was vested with individuals' freedoms and relatively 'free' markets well before mainland China changed its course. Way back in 1820, per capita GDP of all economies for which we have data was relatively low, but the USA and the UK were already quite far ahead of other economies, having sustained considerable economic growth. But most people were living in extreme poverty.

To reiterate, there is an obvious positive relationship between the rise of global capitalism and massive improvements to the socio-economic wellbeing of the world's population. But the hypothesis put forth in this book, accommodated in the theoretical frameworks articulated here, is that one critical reason for the rise and spread of these massive improvements to the human condition was the ability of individuals to effectively struggle for a more ethical capitalism. This struggle has been facilitated by rapid economic growth which tightened labour markets, increasing the bargaining power of labour, which strengthened labour's and their communities' ability to secure significant improvement to the human condition. But this could take place only when the state did not and does not intervene to countervail the positive effects of tight labour markets on the bargaining power of labour (Domar, 1970; Galbraith, 1952). Also of significance is how the state governs and mediates market forces and the process of economic growth.

This perspective is reinforced by one of the authors/developers of the Oxford data set. Ortiz-Ospina (2017) argues that:

It is true that the historical reduction of extreme poverty around the world happened as markets liberalized and capitalism flourished. But it is also true that this reduction of poverty and improvement of living conditions happened at the time that public spending and redistribution to the worst off reached by far the highest levels ever. The point we want to emphasize is that the world economy has changed in many ways in the last two centuries; and while globalization has been a key factor contributing to raising living standards across the world, its positive effects have been modulated by public policies, particularly social transfers.

A related hypothesis, incorporated in the modelling presented in this book, is that ethical practices can incentivize a more productive and innovative economy as well as a fairer economy by positively affecting productivity. In this sense, we can have our ethical cake and eat it too. The state can play a positive role in this process by supporting ethical practices, including social programmes, infrastructure and institutions, 
which we argue can have a positive effect on efficiency and overall productivity. Facilitating, implementing and enforcing ethical practices can fuel economic growth and development. The role of the state in facilitating, encouraging or impeding ethical practices is critically important. Educating people on what ethical practices are practical and feasible and empowering people to make ethical choices becomes of fundamental importance in determining the extent to which a society becomes more or less ethical. This reiterates the importance placed, most recently, on ethical education by Bowles (2016), DeMartino (2011), Frank et al. (1993) and McCloskey (2006b). Also, empowering consumers can serve to incentivize ethical practices fuelling the type of growth that has evolved globally, especially in the past 100-odd years.

\section{The Ethics of Free Will and Freedom of Choice and Implications for Public Policy}

Another point of focus and contribution of this book is offering an alternative perspective on preference formation, revealed preferences, freedom of choice, and their links to the ethics of respecting or not the choices of individuals. The alternative perspective has a bearing on an understanding of the roots of errors in decision-making and sub-optimal choices amongst rational or smart individuals in the real world of bounded rationality. This, in turn, speaks to the relatively recent attention given to the assumed hardwired systemically biased decisions of the typical individual by the heuristics and biases perspective in behavioural economics. This has given rise to the nudging narrative and the ethics of overriding the free will of individuals and the choices that they make (Berlin, 1969; Thaler and Sunstein, 2008).

The fundamental point that I make is that typically individuals are rational or smart, but this does not mean that errors in decision-making and sub-optimal choices can't be highly significant, causing harm to the individual decision-maker and to society at large. But errors in decision-making might very well be related to individuals' decisionmaking capabilities and their decision-making environment. In this case, the resolution to 'problems' related to preference formation and choices lies more with improving the decision-making capabilities of individuals and their decision-making environment. This would be as opposed to nudging, especially hard nudging and manipulating decision-making outcomes to coincide with the preferences of experts on choice or choice architects as they are referred to by Thaler and Sunstein.

From the perspective of the smart individual or smart agent approach taken in this book, free will and freedom of choice are respected. This is 
an important ethical stance. Otherwise, it is ethical, as a default position, to override the true preferences and choices of individuals even if these choices cause no harm to others. And then it is assumed that the expert, the state, and its representatives know best what is in the best interests of each and every member of society. But this respect for consumer and individual choice enunciated in this book must be nuanced by an understanding of the process of preference formation and the circumstances under which choices are made. This will help us to better understand the conditions required for individuals to achieve their true preferences and the choices that flow from these.

\section{REFERENCES}

Akerlof, G.A. (1970). "The market for 'lemons": quality uncertainty and the market mechanism', Quarterly Journal of Economics, 84: 488-500.

Akerlof, G.A. (2002). 'Behavioral macroeconomics and macroeconomic behavior', American Economic Review, 92: 411-33.

Akerlof, G.A. and R.J. Shiller (2009). Animal Spirits: How Human Psychology Drives the Economy, and Why It Matters for Global Capitalism. Princeton, NJ: Princeton University Press.

Altman, M. (2009). 'History and theory of cooperatives', in Helmut Anheier and Stefan Toepler (eds), International Encyclopedia of Civil Society. New York: Springer, pp. 562-9.

Altman, M. (2010). 'A behavioral and institutional foundation of preference and choice behavior: freedom to choose and choice x-inefficiencies', Review of Social Economy, 69: 395-411.

Altman, M. (2014a). 'Mental models, decision-making, bargaining power, and institutional change', Paper presented at the World Interdisciplinary Network for Institutional Research, First International Conference, Institutions that Change the World, Greenwich, London, 11-14 September.

Altman, M. (2014b). 'Are cooperatives a viable business form? Lessons from behavioural economics', in Sonja Novkovic and Tom Webb (eds), Co-operatives in a Post-Growth Era: Towards Co-operative Economics. London: Zed Books, pp. 176-93.

Becker, G.S. (1996). Accounting for Tastes. Cambridge, MA: Harvard University Press.

Berlin, I. (1969). Four Essays on Liberty. Oxford and New York: Oxford University Press.

Bowles, S. (2016). The Moral Economy: Why Good Incentives Are No Substitute for Good Citizens. New Haven, CT: Yale University Press.

Bowles, S. and H. Gintis (2013). A Cooperative Species: Human Reciprocity and Its Evolution. Princeton, NJ: Princeton University Press.

Commons, J.R. (1959). Institutional Economics: Its Place in Political Economy. Madison, WI: University of Wisconsin Press.

Cyert, R. and J.G. March (1963). A Behavioral Theory of the Firm, 2nd edn (1992). Oxford: Blackwell. 
DeMartino, G.F. (2011). The Economist's Oath: On the Need for and Content of Professional Economic Ethics. New York: Oxford University Press.

DeMartino, G.F. and D.N. McCloskey (eds) (2016). The Oxford Handbook of Professional Economic Ethics. New York: Oxford University Press.

Domar, E.D. (1970). 'The causes of slavery or serfdom: a hypothesis', Journal of Economic History, 30: 18-32.

Frank, R.H. (1996). 'Can socially responsible firms survive in a competitive market?', in D.M. Messick and A.E. Tenbrunsel (eds), Codes of Conduct: Behavioral Research into Business Ethics. New York: Russell Sage Foundation, pp. 86-103.

Frank, R.H. (2004). What Price the Moral High Ground? Ethical Dilemmas in Competitive Environments. Princeton, NJ: Princeton University Press.

Frank, R.H., T. Gilovitch and D. Regan (1993). 'Does studying economics inhibit cooperation?', Journal of Economic Perspectives, 7: 159-71.

Friedman, M. (1970). 'The social responsibility of business is to increase its profits', The New York Times Magazine. New York: The New York Times Corporation.

Galbraith, J.K. (1952). American Capitalism: The Concept of Countervailing Power. Boston, MA: Houghton Mifflin.

Gigerenzer, G. (2007). Gut Feelings: The Intelligence of the Unconscious. New York: Viking.

Gintis, H. (2003). 'The hitchhiker's guide to altruism: genes, culture, and the internalization of norms', Journal of Theoretical Biology, 220: 407-18.

Gordon, D. (1996). Fat and Mean: The Corporate Squeeze of Working Americans and the Myth of Managerial 'Downsizing'. New York: Free Press.

Harsanyi, J. (1982). 'Morality and the theory of rational behaviour', in A. Sen and B. Williams (eds), Utilitarianism and Beyond. Cambridge: Cambridge University Press, pp. 39-62.

Hirschman, A.O. (1970). Exit, Voice, and Loyalty: Responses to Decline in Firms, Organizations, and States. Cambridge, MA: Harvard University Press.

Kahneman, D. (2003). 'Maps of bounded rationality: psychology for behavioral economics', American Economic Review, 93: 1449-75.

Kahneman, D. (2011). Thinking Fast and Slow. New York: Farrar, Straus and Giroux.

Leibenstein, H. (1966). 'Allocative efficiency vs. x-efficiency', American Economic Review, 56: 392-415.

McCloskey, D.N. (2006a). The Bourgeois Virtues: Ethics for an Age of Commerce. Chicago, IL: University of Chicago Press.

McCloskey, D.N. (2006b). 'Bourgeois Virtues?', Cato Policy Report, May/June. Available at: https://www.cato.org/sites/cato.org/files/serials/files/policy-report/ 2006/5/cpr-28n3-1.pdf (accessed 7 January 2020).

North, D.C. (1971). 'Institutional change and economic growth', Journal of Economic History, 31: 118-25.

Nussbaum, M. (2000). Women and Human Development: The Capabilities Approach. New York: Cambridge University Press.

Nussbaum, M. (2003). 'Capabilities as fundamental entitlements: Sen and social justice', Feminist Economics, 9: 33-59.

Ortiz-Ospina, H. (2017). 'Historical poverty reductions: more than a story about "free-market capitalism", Our World in Data. Oxford: University of Oxford. Available at: https://ourworldindata.org/historical-poverty-reductions-more-than -a-story-about-free-market-capitalism (accessed 7 January 2020). 
Roser, M., E. Ortiz-Ospina, H. Ritchie, J. Hasell and D. Gavrilov (2019). Our World in Data. Oxford: University of Oxford. Available at: https://ourworldin data.org (accessed 7 January 2020).

Rothschild, K.W. (1992). Ethics and Economic Theory: Ideas, Models, Dilemmas. Aldershot, UK and Brookfield, VT, USA: Edward Elgar.

Sen, A. (1987). Commodities and Capabilities. Oxford: Oxford University Press.

Sen, A. (1988). On Ethics and Economics. Oxford: Blackwell.

Simon, H.A. (1987). 'Behavioral economics', in J. Eatwell, M. Millgate and P. Newman (eds), The New Palgrave: A Dictionary of Economics. London: Macmillan, pp. 266-8.

Smith, A. (1937). An Inquiry into the Nature and Causes of the Wealth of Nations. New York: Modern Library.

Smith, V.L. (2003). 'Constructivist and ecological rationality in economics', American Economic Review, 93: 465-508.

Thaler, R.H. and C. Sunstein (2008). Nudge: Improving Decisions about Health, Wealth, and Happiness. New Haven, CT and London: Yale University Press.

Tversky, A. and D. Kahneman (1981). 'The framing of decisions and the psychology of choice', Science, 211: 453-8.

White, M.D. (ed.) (2019). The Oxford Handbook of Ethics and Economics. Oxford: Oxford University Press. 


\section{APPENDIX: BACKGROUND SOURCES FOR THIS BOOK}

These chapters, apart from Chapters 1 and 2, are derived from the following publications. Chapter 3: Morris Altman (2005). 'Reconciling altruistic, moralistic, and ethical behavior with the rational economic agent and competitive markets', Journal of Economic Psychology, 26: 732-57; and Morris Altman (2005). 'The economics of ethics revisited and importance of economics: a response to the critics', Journal of Economic Psychology, 26: 774-8. Chapter 4: Morris Altman (2006). 'Opening-up the objective function: choice behavior and economic and non-economic variables - core and marginal altruism', Economics Bulletin, 4(33): 1-11. Available at http://www. accessecon.com/pubs/EB/2006/Volume4/EB-06D00022A.pdf (accessed 7 January 2020). Chapter 5: Morris Altman (2006). 'Human agency and free will: choice and determinism in economics', International Journal of Social Economics, 33: 677-97. Chapter 6: Morris Altman (2011). 'Sen's "capabilities" and economic welfare', in R. Chadwick (ed.), Encyclopedia of Applied Ethics, Vol. 4, 2nd edn, Amsterdam: Elsevier Science, pp. 58-67. Chapters 5 and 6 also borrow from Morris Altman (2010). 'A behavioral and institutional foundation of preference and choice behavior: freedom to choose and choice x-inefficiencies', Review of Social Economy, 69: 395-411. Chapter 7 builds on Morris Altman (2016). 'Is there a co-operative advantage? Experimental evidence on the economic and non-economic determinants of demand', Journal of Co-operative Organization and Management, 4: 66-75 and Chapter 8 builds on Morris Altman (2001). 'When green isn't mean: economic theory and the heuristics of the impact of environmental regulations on competitiveness and opportunity cost', Ecological Economics, 36: 31-44. Chapter 9 draws on Morris Altman (2011). 'Behavioural economics, ethics, and public policy: paving the road to freedom or serfdom?', in Jonathan Boston (ed.), Ethics and Public Policy: Contemporary Issues, Wellington: Victoria University Press, pp. 23-48. 